В конце учебного пособия включен список использованной и рекомендованной литературы, специальных словарей грамматического типа и справочников, опубликованных в России и Чешской Республике. Он составлен авторами с учетом авторитетных источников предыдущих лет и новейших работ по морфологии русского языка. Авторы настоящего пособия убеждены, что список источников, опирающийся на самые современные поможет учащимся в учебной деятельности сориентироваться в новейших тенденциях в области современного русского языка.

Алеш Бранднер

https://doi.org/10.5817/OS2018-4-8

\title{
A New Book on Style of Czech Scholarly Texts
}

SCHACHERL, M.: Some Tendencies in Contemporary Scientific Text. České Budějovice: Pedagogická fakulta Jihočeské univerzity, 2018, 212 p., ISBN 978-80-7394-428-5.

The book Some Tendencies in Contemporary Scientific Text by M. Schacherl provides a thorough empirical analysis of various kinds of texts from practically all fields of science, carefully examining selected aspects of their style. Methodologically, this work is based on the functional approach of the Prague School and its successors, stylistics being one of the disciplines in which this approach is still very influential in the context of present-day Czech. However, in this book only one sphere of communication is dealt with, namely the sphere of science in general and within this sphere the types of texts often referred to as theoretical (as distinct e.g. from materials focused on popularizing science, on its practical aspects etc.).

This dominant topic corresponds both with the choice of source texts (their complete list is available in the section dealing with bibliography) and with the selection of the individual investigated aspects, such as the tendency towards using international vs. Czech terminology, some syntactic tendencies, supported also by quantitative data, expressing similarity, using idioms and phrases or expressivity indicated e.g. by the use of quotes. As mentioned above, the work covers a wide range of contemporary theoretical texts, from spheres such as technical sciences, natural sciences, medicine, social sciences and humanities-this wide range provides the possibility to carry out a thorough analysis of interdisciplinary nature, with regard to specific features of the individual disciplines.

The individual partial topics relating to various aspects of means of expression are dealt with very thoroughly, always well supported by the material. Moreover, as 
they are based on detailed analyses of current material, some statements, frequently appearing in the context of Czech scholarly texts, are sometimes modified, as a result of the analysis, and sometimes proved. For example, in all kinds of analysed texts in accordance with general rules, there is a strong tendency towards using international terminology (rather than the particular Czech equivalents), which corresponds with the high level of knowledge of the addressees; yet, a difference e.g. between natural sciences and humanities remains clearly visible here, texts from the sphere of humanities remaining more accessible to recipients in general.

Syntactic means of expression are another partial topic-traditional concepts of long, complex as well as compound sentences were not proved by the analysis; on the contrary-clear and condensed structures were found in all kinds of analysed texts, very often with predicates of limited variability, with low frequency of modal verbs and with frequent plural forms, relating either to author/s or trying to include the addressees into the process of communication-because of different conventions and usage, this individual feature could, in my opinion, make a good point for a comparison e.g. with texts written by native speakers of English.

Rhetorical questions represent another feature that would be traditionally expected in popularizing, rather than in strictly theoretical texts, however, the analysis proves that it can also be found in the analysed sample of texts, performing their essential function, i.e. to activate the addressee and to make the discourse livelier. The same applies to comparisons, with various degrees of metaphorical nature, sometimes expressive, especially in the sphere of social sciences and humanities; this is true also for the use of idioms and phrases.

Some of the analysed features appear only within one particular type of languages, but the influence of such features can also be linked with general issues. This is e.g. the case of congruent attributes, namely of attributes in Czech texts, expressing congruence on the basis of typological features linked with inflection. Such attributes can sometimes work as metaphors, or they can simply be used as means expressing vagueness, relativity or expressivity, bringing thus a higher degree of activity not only in the sphere of social sciences and humanities.

Another analysed feature is of purely graphical nature, namely the quotes-even in the kind of analysed texts they need not serve only for the main purpose, i.e. for marking quotations, but also for other purposes, such as expressing irony, a certain kind of distance from the subject matter etc.

To conclude: although it may seem a bit unusual at first sight to write about Czech texts in English, yet there is one significant advantage of this approach: this book can serve as a very good and reliable basis for a future work focused on style of science. Besides a work focused on other types of texts (e.g. those of popularizing or practical nature) there may also be a starting point for work of a different nature. To be specific, 
it may be a comparative work in the context of any language, carried out by Czech scholars as well as by scholars from abroad, native-speakers as well as non-native speakers of English; this book is a useful source that may facilitate their work and provide them with reliable methodological as well as material basis.

Michal Kř́stek

https://doi.org/10.5817/OS2018-4-9

\section{Záslužný vydavatelský počin: první knižní vydání cenné, avšak téměr̆ zapomenuté práce o vývoji východo- slovenských nářečí}

KOTULIČ, I.: Historické hláskoslovie a tvaroslovie východoslovenských náreči (1957). Bratislava: Veda, 2017. ISBN 978-80-224-1582-8.

V roce 2017 vydal Jazykovedný ústav L'udovíta Štúra SAV v rámci projektu Fonologický vývin slovenčiny vo svetle súčasného stavu historickej jazykovedy kandidátskou disertační práci slovenského jazykovědce PhDr. Izidora Kotuliče, CSc., (1927-2012) Historické hláskoslovie a tvaroslovie východoslovenských nárečí z roku 1957. Kniha byla vydána $\mathrm{k}$ devadesátému výročí autorova narození.

Jedná se o první knižní vydání práce, která dosud byla badatelům známá pouze z četných bibliografických odkazů v monografii Kotuličova učitele a školitele prof. Eugena Paulinyho Fonologický vývin slovenčiny ${ }^{1}$ (a jejím prostřednictvím sekundárně i z dalších prací). Bohužel bylo téměř nemožné nahlédnout do Kotuličovy dizertace, protože se nenacházela $\mathrm{v}$ žádné veřejné ani akademické knihovně na Slovensku. Nynější vydání díla bylo možné jen díky ochotě Kotuličovy rodiny, která zapůjčila soukromý exemplář rukopisu.

Kotulič sám se k přípravě textu pro knižní vydání bohužel nikdy nedostal. To by vyžadovalo další usilovnou a časově náročnou práci, bylo by potřeba vypořádat se s připomínkami oponentů, tedy provést v textu řadu formálních i koncepčních změn. V neposlední řadě byla komplikací i absence závěru, který do termínu odevzdání práce autor nestihl vypracovat. Po získání vědecké hodnosti se Kotulič začal věnovat náročnému a dlouhodobému procesu budování základny pro Historický slovník

1 PAULINY, E.: Fonologický vývin slovenčiny. Bratislava: Vydavatel'stvo Slovenskej akadémie vied, 1963. 